\title{
Pengaruh belanja modal dan penanaman modal dalam negeri terhadap pertumbuhan ekonomi di Kabupaten/Kota Provinsi Jambi
}

\author{
Haikal Redho Fitrah; Syaparudin; Emilia \\ Prodi Ekonomi Pembangunan Fak. Ekonomi dan Binsis Universitas Jambi \\ *E-mail korespodensi: toolhaikal@gmail.com
}

\begin{abstract}
This study aims to: 1) analyze the development of Capital Expenditure, PMDN and Regency and City Economic Growth in Jambi Province; 2) To find out and analyze the effect of Capital Expenditures and Domestic Investment on the Regency and City Economic Growth in Jambi Province. The research analysis tool uses panel data regression analysis tools. Based on the regression test results, the data of the simultaneous data shows that capital expenditure and PMDN have a significant effect on the economic growth of regencies/cities in Jambi Province. While partially leading the two independent variables, only PMDN affects economic growth in Jambi Province districts/cities, while capital expenditure does not affect economic growth in Jambi Province districts/cities during 2011-2017.
\end{abstract}

Keywords: Capital expenditure, PMDN, Economic growth

\begin{abstract}
Abstrak
Penelitian ini bertujuan untuk: 1) menganalisis perkembangan Belanja Modal, PMDN dan Pertumbuhan Ekonomi Kabupaten dan Kota di Provinsi Jambi; 2) Untuk mengetahui dan menganalisis pengaruh Belanja Modal dan PMDN terhadap Pertumbuhan Ekonomi Kabupaten dan Kota di Provinsi Jambi. Alat analisis penelitian menggunakan alat analisis regresi data panel. Berdasarkan hasil uji regresi data penel secara simultan menunjukkan belanja modal dan PMDN berpengaruh signifikan terhadap pertumbuhan ekonomi kabupaten/kota di Provinsi Jambi. Sedangkan secara parsial menunjukkan dari kedua variabel bebas hanya PMDN yang berpengaruh terhadap pertumbuhan ekonomi di kabupaten/kota Provinsi Jambi, sementara belanja modal tidak berpengaruh terhadap pertumbuhan ekonomi di kabupaten/kota Provinsi Jambi selama tahun 2011-2017.
\end{abstract}

Kata Kunci: Belanja modal, PMDN, Pertumbuhan ekonomi

\section{PENDAHULUAN}

Salah satu indikator keberhasilan pembangunan di suatu daerah adalah pertumbuhan ekonomi secara keseluruhan maupun pertumbuhan ekonomi sektoral. Pertumbuhan ekonomi yang tinggi diharapkan dapat meningkatkan taraf hidup masyarakat yang ada, yang pada akhirnya dapat mencapai kemakmuran suatu bangsa dan daerah.

Pembangunan pada dasarnya bertujuan untuk mencapai kemakmuran dan kesejahteraan masyarakat. Pembangunan juga meliputi perubahan dalam tingkat pertumbuhan ekonomi, pengurangan ketimpangan pendapatan dan pemberantasan kemiskinan. Untuk mencapai sasaran yang diingi nkan, maka pembangunan suatu negara dapat diarahkan pada tiga hal pokok yaitu: meningkatkan ketersediaan dan distribusi kebutuhan pokok bagi masyarakat, meningkatkan standar hidup masyarakat dan meningkatkan kemampuan masyarakat dalam mengakses baik kegiatan ekonomi maupun kegiatan social dalam kehidupannya (Todaro, 2004). 
Pertumbuhan ekonomi menjadi salah satu indikator tingkat kesejahterahan penduduk suatu negara ataupun daerah. Dengan tercapainya pertumbuhan ekonomi yang tinggi dan pemerataan pendapatan, maka secara langsung akan berdampak pada berkurangnya jumlah penduduk yang tergolong miskin. Oleh karena itu, upaya pengentasan kemiskinan harus dilakukan secara komprehensif, mencakup berhagai aspek kehidupan dan dilakukan secara berkesinambungan. Perencanaan merupakan sebuah upaya untuk mengantisipasi ketidakseimbangan yang terjadi yang bersifat akumulatif.

Pertumbuhan ekonomi di suatu daerah dapat memberikan gambaran mengenai upaya yang telah dilakukan oleh pemerintah daerah dalam melaksanakan kegiatan pembangunan daerah. Pertumbuhan ekonomi di suatu daerah dapat ditunjukan oleh pertumbuhan Produk Domestik Regional Bruto daerah tersebut. Berikut adalah gambaran umum mengenai laju pertumbuhan ekonomi provinsi - provinsi yang berada di Pulau Sumatera :

Tabel 1. Laju pertumbuhan PDRB atas dasar harga konstan 2010 menurut Provinsi di Pulau Sumatera, 2011-2017

\begin{tabular}{lcccccccc}
\hline \multirow{1}{*}{ Provinsi } & \multicolumn{7}{c}{ Pertumbuhan Ekonomi (\%) } & \multirow{2}{*}{ Rata-rata } \\
\cline { 2 - 8 } & $\mathbf{2 0 1 1}$ & $\mathbf{2 0 1 2}$ & $\mathbf{2 0 1 3}$ & $\mathbf{2 0 1 4}$ & $\mathbf{2 0 1 5}$ & $\mathbf{2 0 1 6}$ & $\mathbf{2 0 1 7}$ & \\
\hline Aceh & 3,28 & 3,85 & 2,61 & 1,55 & $-0,73$ & 3,31 & 3,58 & 2,49 \\
Sumatera Utara & 6,66 & 6,45 & 6,07 & 5,23 & 5,1 & 5,18 & 5,56 & 5,75 \\
Sumatera Barat & 6,34 & 6,31 & 6,08 & 5,88 & 5,52 & 5,26 & 5,39 & 5,83 \\
Riau & 5,57 & 3,76 & 2,48 & 2,71 & 0,22 & 2,23 & 2,91 & 2,84 \\
Jambi & 7,86 & 7,03 & 6,89 & 7,36 & 4,2 & 4,37 & 4,76 & 6,07 \\
Sumatera Selatan & 6,36 & 6,83 & 5,31 & 4,79 & 4,42 & 5,03 & 5,57 & 5,47 \\
Bengkulu & 6,85 & 6,83 & 6,07 & 5,48 & 5,13 & 5,3 & 4,9 & 5,79 \\
Lampung & 6,56 & 6,44 & 5,77 & 5,08 & 5,13 & 5,15 & 5,21 & 5,62 \\
Kepulauan Bangka Belitung & 6,9 & 5,5 & 5,2 & 4,67 & 4,08 & 4,11 & 3,6 & 4,87 \\
Kepulauan Riau & 6,96 & 7,63 & 7,21 & 6,6 & 6,01 & 5,03 & 2,57 & 6,00 \\
\hline
\end{tabular}

Sumber : bps.go.id, 2019(diolah)

Dari data pada Tabel 1 tersebut terlihat laju pertumbuhan ekonomi ProvinsiProvinsi yang di berada Pulau Sumatera mengalami fluktuasi tiap tahunnya. Provinsi dengan laju pertumbuhan tertinggi yaitu Provinsi Jambi dengan rata-rata pertumbuhan ekonomi sebesar 6,07 persen, sedangkan Provinsi dengan laju pertumbuhan ekonomi terendah yaitu Provinsi Aceh dengan rata-rata pertumbuhan ekonomi sebesar 2,49 persen. Tingginya rata-rata pertumbuhan ekonomi di Provinsi Jambi tidak terlepas dari peran investasi pemerintah maupun swasta.

Provinsi Jambi sendiri dianugerahi oleh melimpahnya sumber daya alam seperti buah sawit, karet, batubara dan buah pinang yang membuat Provinsi Jambi menjadi salah satu Provinsi penggerak roda perekonomian di Indonesia. Potensi sumber daya yang melimpah ini menjadi daya tarik tersendiri bagi investor untuk mulai berinvestasi di daerah tersebut. Namun potensi besar yang ditawarkan daerah tidak serta merta membuat investor bersedia untuk berinvestasi. Banyak faktor yang perlu dipertimbangkan oleh investor untuk mulai berinvestasi seperti faktor infrastruktur, perizinan, keamanan, ketersediaan tenaga kerja dan lain-lain. Oleh karena itu Pemerintah Daerah perlu memberikan perhatian terhadap faktor - faktor penunjang iklim investasi di daerah dalam bentuk belanja modal karena dengan semakin meningkatnya iklim investasi maka akan meningkatkan kegiatan perekonomian di daerah yang pada akhirnya akan menciptakan kesejahteraan masyarakat di daerah tersebut.

Dewasa ini banyak negara-negara yang melakukan kebijaksanaan yang bertujuan untuk meningkatkan investasi dari sisi penanaman modal dalam negeri. Hal ini dilakukan oleh pemerintah sebab kegiatan investasi akan mendorong pula kegiatan ekonomi suatu 
negara, penyerapan tenaga kerja, peningkatan output yang dihasilkan, penghematan devisa atau bahkan penambahan devisa. Menurut Husnan (2012) menyatakan bahwa "proyek investasi merupakan suatu rencana untuk menginvestasikan sumber-sumber daya, baik proyek raksasa ataupun proyek kecil untuk memperoleh manfaat pada masa yang akan datang." Pada umumnya manfaat ini dalam bentuk nilai uang. Sedang modal, bisa saja berbentuk bukan uang, misalnya tanah, mesin, bangunan dan lain-lain. Namun baik sisi pengeluaran investasi ataupun manfaat yang diperoleh, semua harus dikonversikan dalam nilai uang. Suatu rencana investasi perlu dianalisis secara seksama.

Pertumbuhan ekonomi adalah suatu proses dimana terjadi kenaikan produk nasional bruto riil suatu perekonomian riil atau pendapatan riil. Jadi suatu perekonomian dapat dikatakan tumbuh atau berkembang bila terjadi output riil. Pertumbuhan ekonomi juga didefinisikan sebagai peningkatan dalam kapasitas suatu bangsa dalam jangka panjang untuk memproduksi aneka barang dan jasa bagi masyarakat, kapasitas ini bertumpu pada kemajuan teknologi produksi (Gerardo,P, dkk, 1991).

Lebih lanjut, Wagner menyebutkan bahwa dalam suatu perekonomian apabila pendapatan per kapita meningkat, secara relatif pengeluaran pemerintah pun akan meningkat (Mangkoesoebroto, 1997 dalam Hendarmin, 2012). Sehingga secara tidak langsung ataupun langsung dalam hal dikehendaki PDB secara agregat atau pendapatan perkapita meningkat harus diikuti dengan meningkatnya nilai pengeluaran pemerintah. Dengan semakin tinggi tingkat investasi modal diharapkan mampu meningkatkan kualitas layanan publik dan pada gilirannya mampu meningkatkan tingkat partisipasi publik terhadap pembangunan (Mardiasmo, 2002 dalam Adi, 2006).

Selama investasi netto tetap berlangsung, maka pendapatan riil dan output akan senantiasa membesar (Sukirno,2004). Teori Harrod-Domar merupakan perluasan dari teori Keynes yang melihat pertumbuhan ekonomi dari segi permintaan yaitu bahwa pertumbuhan ekonomi akan terjadi ketika ada kenaikan investasi (Arsyad,2010). Berdasarkan teori Pertumbuhan Ekonomi dari Harrod Domar menerangkan bahwa adanya korelasi positip antara tingkat investasi dan laju pertumbuhan ekonomi. Artinya rendahnya Investasi disuatu wilayah membuat pertumbuhan ekonomi dan tingkat pendapatan masyarakat perkapita di wilayah tersebut rendah karena tidak ada kegiatan kegiatan ekonomi yang produktif.

Analisis rencana investasi pada dasarmya merupakan penelitian tentang dapat tidaknya suatu proyek (baik besar atau kecil) dapat dilaksanakan dengan berhasil, atau suatu metode penjajakkan dari suatu gagasan usaha/bisnis tentang kemungkinan layak atau tidaknya gagasan usaha/bisnis tersebut dilaksanakan. Suatu proyek investasi umumnya memerlukan dana yang besar dan akan mempengaruhi perusahaan dalam jangka panjang. Oleh karena itu dilakukan perencanaan investasi yang lebih teliti agar tidak terlanjur menanamkan investasi pada proyek yang tidak menguntungkan dan tidak berdampak pada pertumbuhan ekonomi.

Berdasarkan data yang dihimpun dari Direktorat Jenderal Perimbangan Keuangan \& BPS Provinsi Jambi dapat dianalisis bahwa bahwa nilai realisasi belanja modal selama tahun 2011-2017 cenderung mengalami peningkatan setiap tahunnya, begitu juga dengan PMDN akan tetapi pertumbuhan ekonomi masih mengalami fluktuasi setiap tahunnya. Fenomena terjadi pada tahun 2014 dimana belanja modal mengalami penurunan sebesar -12,79 persen atau menurun dari Rp.938 milyar menjadi Rp.818 milyar, namun pada tahun yang sama pertumbuhan ekonomi meningkat sebesar 7,36, seharusnya menurnnya belanja modal akan menurunkan pertumbuhan ekonomi. Selanjutnya penurunan belanja modal sebesar -3,30 atau menurun dari Rp.818 milyar mnejadi Rp.791 milyar pada tahun 2015 seiring dengan menurunnya pertumbuhan ekonomi namun pada tahun yang sama PMDN mengalami peningkatan, seharunya peningkatan PMDN dapat meningkatkan pertumbuhan ekonomi. Secara rata-rata selama tahun 2011 sampai tahun 2017 belanja modal mengalami peningkatan sebesar 18,07 persen setiap tahunnya, PMDN meningkat 
sebesar 17,65 persen setiap tahunnya dan pertumbuhan ekonomi meningkat 5,77 persen setiap tahunnya.

Santoso (2016) dalam jurnalnya yang berjudul "Pengaruh Belanja Modal, PMA dan PMDN terhadap pertumbuhan ekonomi dan implikasinya terhadap PAD studi pada kabupaten/kota di Provinsi Jawa Barat selama tahun 2008-2013. Penelitian ini menggunakan data sekunder dengan metode analisis regresi data panael. Hasil penelitiannya menyebutkan bahwa belanja modal, PMA dan PMDN mempunyai pengaruh signifikan dan berpengaruh positif terhadap pertumbuhan ekonomi karena nilai probabilita masing-masing variabel independen lebih kecil dari alpha 5 persen, sementara pertumbuhan ekonomi juga berpengaruh signfikan dan positi terhadap PAD.

Daniel (2015) dalam jurnalnya yang berjudul " Analisis pengaruh pengeluaran pemerintah dan investasi terhadap kesempatan kerja, pertumbuhan ekonomi serta ketimpangan pendapatan periode tahun 2005-2013". Teknik analisis data yang digunakan dalam penelitian ini adalah analisis jalur (path analysis). Penelitian ini menyimpulkan; (1) Pengeluaran pemerintah secara langsung berpengaruh positif terhadap kesempatan kerja; (2) Pengeluaran pemerintah mempunyai pengaruh positif dan signifikan terhadap kesenjangan pendapatan; (3)Investasi secara langsung berpengaruh positif dan signifikan terhadap kesempatan kerja; (4) Investasi secara langsung menunjukkan pengaruh positif dan signifikan terhadap pertumbuhan ekonomi; (5) Investasi secara langsung berpengaruh positif terhadap ketimpangan pendapatan pendapatan; (6) Kesempatan kerja secara langsung berpengaruh positif terhadap pertumbuhan ekonomi; (7) Kesempatan kerja secara langsung berpengaruh positif dan signifikan terhadap ketimpangan distribusi pendapatan; (8) Pertumbuhan ekonomi secara langsung berpengaruh positif dan signifikan terhadapketimpangan pendapatan; (9) Pengeluaran pemerintah secara tidak langsung berpengaruh positif dan signifikan terhadap pertumbuhan ekonomi melelui kesempatan kerja; (10) Pengeluaran pemerintah secara tidak langsung mempunyai pengaruh positif terhadap ketimpangan pendapatan melalui kesempatan kerja dan pertumbuhan ekonomi dan pengaruh positif membawa penurunan ketimpangan pendapatan yang artinya pendapatan dapat lebih merata; (11) Investasi secara tidak langsung berpengaruh positif terhadap pertumbuhan ekonomi melalui kesempatan kerja, namun peningkatan pertumbuhan ekonomi masih lebih rendah daripada sebelum mediasi; (12) Investasi secara tidak langsung berpengaruh positif terhadap ketimpangan pendapatan melalui kesempatan kerja dan pertumbuhan ekonomi. Setelah melalui mediasi kesempatan kerja dan pertumbuhan ekonomi, ketimpangan pendapatan semakin tinggi dan timpang; (13) Kesempatan kerja secara tidak langsung berpengaruh positif terhadap ketimpangan pendapatan melalui pertumbuhan ekonomi kabupaten/kota di Provinsi Bali, namun pengaruh positif membawa penurunan ketimpangan pendapatan yang artinya pendapatan dapat lebih merata.

Provinsi Jambi terdiri dari 11 wilayah kabupaten/kota yang mempunyai keanekaragaman potensi sumberdaya, baik sumberdaya alam maupun sumberdaya manusia, sehingga iklim investasi pada masing-masing wilayah kabupaten/kota di Provinsi Jambi juga berbeda-beda. Tentunya pertumbuhan ekonomi di kabupaten/kota di Provinsi Jambi juga berbeda-beda. Jika dilihat data pertumbuhan ekonomi di Provinsi Jambi mengalami perkembangan yang berfluktuatif, namun realisasi belanja modal setiap tahunnya meningkat. PMDN juga cendrung meningkat, namun penelitian ini tidak akan memasukkan wilayah kabuapetan kerinci dan Kota Sunga Penuh dikarenakan hanya 4 tahun terakhir adanya PMDN masuk kedua wilayah ini. Perkembangan belanja modal dan PMDN tidak seiring dengan perkembangan pertumbuhan ekonomi. Seharusnya meningkatnya belanja modal dan PMDN akan meningkatkan pertumbuhan ekonomi di Provinsi Jambi.

Berdasarkan fenomena tersebut, penulis tertarik untuk meneliti pengaruh belanja Modal dan investasi dalam negeri terhadap Pertumbuhan Ekonomi di Kabupaten dan 
Kota di Provinsi Jambi. Yang membedakan penelitian ini dengan penelitian sebelumnya terletak pada objek yang diteliti yaitu Kabupaten dan Kota di Povinsi Jambi. Selain itu penelitian ini menggunakan data rentang waktu tahun 2011-2017. Penelitian skripsi ini penulis beri judul "Pengaruh Belanja Modal dan Penanaman Modal dalam Negeri Terhadap Pertumbuhan Ekonomi di Kabupaten/Kota Provinsi Jambi”.

\section{METODE}

Metode penelitian yang digunakan dalam penelitian ini adalah metode analisis data sekunder. Metode analisis data sekunder adalah suatu metode dalam menganalisis suatu permasalahan atau fenomena dalam ekonomi dengan menggunakan data yang telah dikumpulkan, diolah, disajikan dan dilaporkan oleh pihak lain (Nasir, 2001). Metode pengumpulan data sekunder sering disebut dengan penggunaan bahan dokumen. Karena dalam hal ini peneliti tidak langsung melakukan penelitian sendiri tetapi meneliti dan memanfaatkan data yang telah dihasilkan oleh pihak lain.

\section{Jenis dan sumber data}

\section{Jenis data}

Data yang digunakan dalam penelitian ini adalah data sekunder berupa data deret waktu (time series data) selama kurun waktu tahun 2011-2017 dan data deret lintang (cross section data) yang meliputi 9 kabupaten/kota di Provinsi Jambi. Data yang digunakan dalam penelitian ini adalah sebagai berikut: 1).Realisasi Belanja Modal Kabupaten/Kota Provinsi Jambi periode 2011 - 2017, 2).Realisasi Investasi PMDN Kabupaten/Kota Provinsi Jambi periode 2011 - 2017, 3).Pertumbuhan Ekonomi Kabupaten/Kota Provinsi Jambi periode 2011 - 2017.

\section{Sumber data}

Data yang digunakan dalam penelitian ini, dikumpulkan dari publikasi dan informasi data serta laporan-laporan yang dilakukan oleh dinas dan instansi terkait. Untuk memperoleh landasan teori, studi sebelumnya dan kerangka pemikiran dilakukan studi kepustakaan berupa buku-buku literatur.

Sumber data yang digunakan dalam penelitian ini berasal dari :1).BPS Provinsi Jambi, 2).Direktorat Jenderal Perimbangan Keuangan, 3).Dinas Penanaman Modal dan PTSP

\section{Metode analisis data}

Metode analisis dalam penelitian ini adalah metode deskriptif dengan pendekatan kualitatif dan kuantitatif. Analisis kualitatif digunakan untuk menggambarkan dan menguraikan keadaan persoalan yang didukung oleh fakta, sifat-sifat serta hubungan antara fenomena yang dianalisis, sementara analisis kuantitatif digunakan untuk mengolah data menggunakan regresi data panel.

\section{Model analisis pertama}

Untuk menjawab permasalahan dan tujuan penelitian yang pertama menurut Halim (2004) digunakan rumus berikut:

$$
\mathrm{Gx}=\frac{X_{t}-X_{t-1}}{X_{t-1}} \times 100
$$


Dengan menggunakan rumus diatas maka dapat dimasukkan variabel-variabel yang digunakan dalam penelitian ini guna untuk mengetahui bagaimana perkembangan realisasi belanja modal, PMDN dan pertumbuhan ekonomi di kabupaten/kota Provinsi Jambi.

$$
\begin{aligned}
& G_{B M}=\frac{B M_{t}-B M_{t-1}}{B M_{t-1}} \times 100 \\
& G_{P M D N}=\frac{P M D N_{t}-P M D N_{t-1}}{P M D N_{t-1}} \times 100 \\
& G_{P E}=\frac{P D R B_{t}-P D R B_{t-1}}{P D R B_{t-1}} \times 100
\end{aligned}
$$

Dimana :

$\mathrm{G}_{\mathrm{PE}} \quad=$ Perkembangan pertumbuhan ekonomi

$\mathrm{G}_{\mathrm{BM}} \quad=$ Perkembangan belanja modal $\mathrm{t}$

GPMDN $\quad=$ Perkembangan penanaman modal dalam negeri

$\mathrm{G}_{\mathrm{PDRB}} \quad=$ PDRB tahun pertama

$\mathrm{G}_{\mathrm{BMt}} \quad=$ Belanja modal tahun pertama

GPMDNt = Penanaman modal dalam negeri provinsi tahun pertama

$\mathrm{G}_{\mathrm{PDRB}(\mathrm{t}-1)}=\mathrm{PDRB}$ tahun sebelumnya

$\mathrm{G}_{\mathrm{BM}(\mathrm{t}-1)}=$ Belanja modal tahun sebelumnya

$\mathrm{G}_{\mathrm{PMDN}(\mathrm{t}-1)}=$ Penanaman modal dalam negeri tahun sebelumnya

\section{Model analisis kedua}

Model analisis kedua merupakan alat analisis yang digunakan untuk melihat sejauh mana pengaruh variabel bebas Belanja Modal dan PMDN terhadap Pertumbuhan Ekonomi Kabupaten/kota di Provinsi Jambi tahun 2011-2017. Adapun model regresi yang digunakan adalah sebagai berikut (Gujarati,2011) :

$\mathbf{Y}_{\mathrm{it}}=\alpha+\alpha_{1} \mathbf{X}_{1 \mathrm{it}}+\alpha_{2} \mathbf{X}_{2 \mathrm{it}}+\mathbf{e}_{\mathrm{it}}$

Selanjutnya diubah menjadi persamaan berikut :

PEit $=\alpha+\alpha_{1} B_{i t}+\alpha_{2} P M D N i t+e_{i t}$

Dimana:

PEit = Pertumbuhan ekonomi

BMit = Belanja modal

PMDNit $=$ PMDN

$\boldsymbol{\alpha} 1, \boldsymbol{\alpha} 2=$ Koefisien masing-masing variabel

$\boldsymbol{\alpha} 0=$ Konstanta

e $\quad=$ Kesalahan pengganggu (stokastik)

\section{HASIL DAN PEMBAHASAN}

\section{Pengaruh belanja modal dan PMDN terhadap pertumbuhan ekonomi Kabupaten/Kota di Provinsi Jambi}

Bagian ini akan menjelaskan bagaimana pengaruh belanja modal dan PMDN terhadap pertumbuhan ekonomi yang menggunakan perhitungan regresi data panel yaitu menggunakan data time series adalah data tahunan t yaitu tahun 2011-2017 dan cross 
section adalah objek data yaitu meliputi 9 kabupaten/kota yang ada di Provinsi Jambi. Variabel bebas yang belanja modal, PMDN dan variabel terikatnya adalah pertumbuhan ekonomi.

\section{Hasil uji estimasi model data panel}

Untuk menentukan model yang paling tepat digunakan dalam mengestimasi data panel, maka akan dilakukan pengujian pemilihan model dengan menggunakan Uji Chow atau Likelihood Tes Radio dan Uji Hausman. Berikut ini akan ditampilkan hasil pengujian tersebut:

\section{Chow test (uji chow)} dan FEM.

Dilakukan untuk membandingkan/memilih model mana yang terbaik antara PLS

Tabel 2. Uji chow untuk memilih antara model PLS dengan FEM

Redundant Fixed Effects Tests

Pool: POOL01

Test cross-section fixed effects

\begin{tabular}{lrrr}
\hline Effects Test & Statistic & d.f. & Prob. \\
\hline Cross-section F & 3.523413 & $(8,52)$ & 0.0025 \\
Cross-section Chi-square & 27.286651 & 8 & 0.0006 \\
\hline Sumber: Data diolah, 2019 & & &
\end{tabular}

Berdasarkan output Eviews tersebut menunjukan bahwa baik F test maupun ChiSquare signifikan (Prob. 0,0006 lebih kecil dibandingkan alfa 0,05), sehingga model ini hipotesis Ho ditolak dan H1 diterima. Dengan demikian, dapat disimpulkan bahwa model FEM lebih baik dibandingkan model PLS.

\section{Hausman test (uji hausman)} dan REM

Dilakukan untuk membandingkan/memilih model mana yang terbaik antara FEM

Tabel 3. Uji hausman untk memilih antara model FEM dengan REM

Correlated Random Effects - Hausman Test

Pool: POOL01

Test cross-section random effects

\begin{tabular}{lrrr}
\hline Test Summary & Chi-Sq. Statistic & Chi-Sq. d.f. & Prob. \\
\hline Cross-section random & 12.178082 & 2 & 0.0023 \\
\hline Sumber: Data diolah, 2019 & & &
\end{tabular}

Berdasarkan output Eviews tersebut menunjukan bahwa nilai statistic Chi-Square memiliki Prob lebih kecil dibandingkan alfa 0,05 $(0,0023<0,05)$, sehingga hipotesis $\mathrm{H}_{0}$ ditolak dan $\mathrm{H}_{1}$ diterima. Dengan demikian dapat disimpulkan bahwa model FEM lebih baik dibandingkan REM. Maka berdasarkan hasil pengujian tersebut dapat diketahui model yang digunakan dalam penelitian ini adalah Model Fixed Effect (FEM). 


\section{Hasil pengujian estimasi model FEM}

Hasil estimasi persamaan data panel tentang pengaruh belanja modal, PMDN dan PMA terhadap pertumbuhan ekonomi adalah sebagai berikut:

Tabel 4 Hasil estimasi metode fixed effect (FEM)

Dependent Variable: PE?

Method: Pooled Least Squares

Total pool (balanced) observations: 63

\begin{tabular}{lrrrr}
\hline \hline Variable & Coefficient & Std. Error & t-Statistic & Prob. \\
\hline \hline C & 35.33926 & 8.710270 & 4.057194 & 0.0002 \\
BM? & 1.492374 & 1.442969 & 1.034239 & 0.3058 \\
PMDN? & 3.560701 & 1.093411 & 3.256507 & 0.0020 \\
Fixed Effects (Cross) & & & \\
_Merangin--C & -0.007135 & & & \\
_Sarolangun--C & -1.692281 & & & \\
_Batanghari--C & 0.502501 & & & \\
_Muarojambi--C & 1.339154 & & & \\
_Tanjabtim--C & -5.913073 & & & \\
_Tanjabbar--C & 3.297377 & & & \\
_Tebo--C & -0.906139 & & & \\
_Bungo--C & 1.981668 & & & \\
_Kotajambi--C & 1.397928 & & & \\
\hline \hline
\end{tabular}

Cross-section fixed (dummy variables)

\begin{tabular}{lrll}
\hline \hline & 0.436831 & Mean dependent var & 6.117460 \\
R-squared & 0.328529 & S.D. dependent var & 1.780012 \\
Adjusted R-squared & 1.458601 & Akaike info criterion & 3.750148 \\
S.E. of regression & 110.6309 & Schwarz criterion & 4.124346 \\
Sum squared resid & -107.1297 & Hannan-Quinn criter. & 3.897322 \\
Log likelihood & 4.033457 & Durbin-Watson stat & 1.476322 \\
F-statistic & 0.000400 & & \\
Prob(F-statistic) & & & \\
\hline
\end{tabular}

Sumber: Data diolah, 2019

\section{Koefisien determinasi $\left(\mathbf{R}^{2}\right)$}

Dari hasil pengujian diperoleh koefisien determinasi $\left(\mathrm{R}^{2}\right)$ sebesar 0,4368 artinya sebesar 43,68 persen variasi pertumbuhan ekonomi dijelaskan oleh variabel bebas dalam model belanja modal dan PMDN sedangkan sisanya 56,32 persen dijelaskan oleh variabel lain diluar peneitian.

\section{Uji F statistic}

Dapat dilihat pada tabel 4 diatas diketahui juga bahwa nilai Prob (f Statistik) 0,0004 $<0,05$, maka berarti Ho ditolak dan menerima Ha, yang artinya uji secara bersama sama menunjukkan belanja modal dan PMDN secara simultan berpengaruh signifikan terhadap pertumbuhan ekonomi kabupaten/kota di Provinsi Jambi. 


\section{Uji t statistik}

Untuk menguji signifikasi pengaruh belanja modal dan PMDN terhadap pertumbuhan ekonomi kabupaten/kota di Provinsi Jambi secara parsial maka digunakan uji t statistik. Uji t Statistik berguna untuk melihat besarnya pengaruh masih-masing variabel independen terhadap variabel dependen secara parsial. Tingkat kepercayaan 95 persen dengan uji dua arah dan $\mathrm{df}=59(\mathrm{n}=63-4)$ nilai $\mathrm{t}$ tabel yang diperoleh adalah 1,671 digunakan alat uji t Statistik yang dapat di lihat di tabel berikut ini:

Tabel 5. Nilai $t$ statistik pada metode FEM

\begin{tabular}{rcccl}
\hline \multicolumn{1}{r}{ Variabel } & t Hitung & t Tabel & Prob. & \multicolumn{1}{c}{ Keterangan } \\
\hline Belanja Modal & 1,0342 & 1,671 & 0,3058 & Tidak Signifikan \\
PMDN & 3,2565 & 1,671 & 0,0020 & Signfikan \\
\hline
\end{tabular}

Sumber: Data diolah, 2019

Berdasarkan Tabel 5 dapat diterangkan hasil uji t statistik sebagai berikut:

Diketahui bahwa nilai t hitung variabel belanja modal yaitu 1,0342 dan t tabel 1,671 sehingga nilai t hitung $<\mathrm{t}$ tabel, artinya $\mathrm{H}_{0}$ diterima dan menolak $\mathrm{H}_{\mathrm{a}}$. Jika dilihat dari probabilita sebesar 0,3058 karena Prob >0,05, maka Ho diterima dan Ha ditolak. Ini menunjukkan bahwa belanja modal tidak berpengaruh terhadap pertumbuhan ekonomi kabupaten/kota di Provinsi Jambi. Hasil ini tidak sependapat dengan teori yang dikemukakan oleh Rostow dan Musgrave yang mengatakan belanja modal dapat mempengaruhi naik/turunnya PDRB karena belanja modal merupakan belanja pembangunan infrastruktur yang dapat menyentuh langsung pada perekonomian masyarakat.. Walaupun belanja modal dan pertumbuhan ekonomi sama-sama mengalami peningkatan yang berfluktuatif akan tetapi secara umum peningkatan realisasi belanja modal relatif lebih rendah dibandingkan PMDN. Selain itu realisasi belanja modal antara kabupaten/kota di Provinsi Jambi tidak merata sehingga belanja modal tidak berpengaruh tehadap pertumbuhan ekonomi kabupaten/kota di Provinsi Jambi tahun 2011 sampai tahun 2017, namun dua variabel ini memiliki hubungan yang positif.

Diketahui bahwa nilai t hitung variabel PMDN yaitu 3,2565 > t tabel 1,671 sehingga $\mathrm{H}_{0}$ ditolak dan menerima $\mathrm{H}_{\mathrm{a}}$. Jika dilihat dari probabilita dari PMDN sebesar 0,0020 karena Prob $<0,05$, maka $\mathrm{H}_{0}$ ditolak dan menerima $\mathrm{H}_{\mathrm{a}}$. Ini menunjukkan bahwa PMDN berpengaruh secara signfikan terhadap pertumbuhan ekonomi kabupaten/kota di Provinsi Jambi. Hasil ini sependapat dengan teori yang dikemukakan oleh Samuelson dan Nordhaus (1993) yang mengatakan Penanaman Modal Dalam Negeri (PMDN) dapat diartikan sebagai pengeluaran atau pembelanjaan penanaman modal atau perusahaan untuk membeli barang-barang produksi, untuk menambah kemampuan memproduksi barang dan jasa yang tersedia dalam perekonomian yang berasal dari investasi dalam negeri. Investasi tersebut menghimpun akumulasi modal dengan membangun sejumlah gedung dan peralatan yang berguna bagi kegiatan produktif, maka output potensial suatu bangsa akan bertambah dan pertumbuhan ekonomi jangka panjang juga akan meningkat. Jelas dengan demikian bahwa investasi khususnya PMDN memainkan peranan penting dalam menentukan jumlah output pendapatan, terutama pada pertumbuhan ekonomi. Berpengaruhnya PMDN terhadap pertumbuhan ekonomi di kabupaten/kota Provinsi Jambi selama tahun 2011-2017 dibuktikan dengan besarnya investasi dalam negeri yang terealisasi untuk meningkatkan produksi pada sektor PDRB sehingga dapat merangsang pertumbuhan ekonomi. Hubungan kedua variabel ini yaitu positif atau searah, artinya jika realisasi PMDN meningkat maka pertumbuhan ekonomi akan meningkat begitu juga sebaliknya. 
Berdasarkan hasil estimasi pada tabel 5 tersebut dapat diketahui penjelasan masing-masing variabel dalam penelitian yaitu belanja modal dan PMDN terhadap pertumbuhan ekonomi dapat dijelaskan persamaan model sebagai berikut:

$$
\begin{array}{lll}
\text { PE }_{\text {it }} & =35,33926+1,4923 L O G B M & +3,5607 \text { LOGPMDN } \\
\text { Prob } & =(0,0000) & (0,3058)
\end{array}
$$

Berdasarkan Persamaan Model tersebut dapat dijelaskan hasil estimasi terhadap Fixed effect adalah jika terjadi perubahan antara belanja modal dan PMDN baik antar wilayah maupun antar waktu, maka nilai konstanta sebesar 35,33 Hal ini berarti belanja modal dan PMDN naik dan variabel lainnya dianggap konstan maka pertumbuhan ekonomi kabupaten/kota di Provinsi Jambi meningkat sebesar 35,33 persen. Nilai koefisien belanja modal sebesar 1,4923. Hal ini diartikan jika belanja modal meningkat satu persen maka pertumbuhan ekonomi kabupaten/kota di Provinsi Jambi meningkat sebesar 1,4923 persen. Nilai koefisien PMDN sebesar 3,5607. Hal ini diartikan jika PMDN meningkat satu persen maka pertumbuhan ekonomi kabupaten/kota di Provinsi Jambi meningkat sebesar 3,5607 persen.

Dari hasil estimasi dengan menggunakan Fixed Effect Model dapat dijelaskan bahwa masing-masing kabupaten/kota di Provinsi Jambi memiliki nilai intersep yang berbeda-beda. Individual Fixed effect dapat dilihat dari tabel berikut ini :

Tabel 6 Fixed effect estimasi model FEM

\begin{tabular}{lc}
\hline \multicolumn{1}{c}{ Kabupaten/Kota } & Fixed Effect \\
\hline Merangin & $-0,415071$ \\
Sarolangun & $-3,232677$ \\
Batang Hari & 0,597184 \\
Muaro Jambi & 1,712361 \\
Tanjung Jabung Timur & $-10,79833$ \\
Tanjung Jabung Barat & 9,217128 \\
Tebo & $-5,002864$ \\
Bungo & 2,716660 \\
Kota Jambi & 1,039890 \\
\hline
\end{tabular}

Sumber: Data diolah, 2019

Berdasarkan estimasi tersebut dapat dilihat bahwa nilai Fixed effect dalam hasil estimasi metode FEM adalah sebagai berikut:

\section{Kabupaten Merangin}

Jika terjadi perubahan belanja modal dan PMDN baik antar wilayah maupun antar waktu, maka Kabupaten Merangin akan mendapatkan pengaruh individual terhadap pertumbuhan ekonomi kabupaten/kota di Provinsi Jambi sebesar -0,415071 persen.

\section{Kabupaten Sarolangun}

Jika terjadi perubahan belanja modal dan PMDN baik antar wilayah maupun antar waktu, maka Kabupaten Sarolangun akan mendapatkan pengaruh individual terhadap pertumbuhan ekonomi kabupaten/kota di Provinsi Jambi sebesar -3,232677 persen.

\section{Kabupaten Batanghari}

Jika terjadi perubahan belanja modal dan PMDN baik antar wilayah maupun antar waktu, maka Kabupaten Batanghari akan mendapatkan pengaruh individual terhadap pertumbuhan ekonomi kabupaten/kota di Provinsi Jambi sebesar 0,597184 persen. 


\section{Kabupaten Muaro Jambi}

Jika terjadi perubahan belanja modal dan PMDN baik antar wilayah maupun antar waktu, maka Kabupaten Muaro Jambi akan mendapatkan pengaruh individual terhadap pertumbuhan ekonomi kabupaten/kota di Provinsi Jambi sebesar 0,1,712361 persen.

\section{Kabupaten Tanjung Jabung Timur}

Jika terjadi perubahan belanja modal dan PMDN baik antar wilayah maupun antar waktu, maka Kabupaten Tanjung Jabung Timur akan mendapatkan pengaruh individual terhadap pertumbuhan ekonomi kabupaten/kota di Provinsi Jambi sebesar -10,79833 persen.

Kabupaten Tanjung Jabung Barat

Jika terjadi perubahan belanja modal dan PMDN baik antar wilayah maupun antar waktu, maka Kabupaten Tanjung Jabung Barat akan mendapatkan pengaruh individual terhadap pertumbuhan ekonomi kabupaten/kota di Provinsi Jambi sebesar 9,217128 persen.

\section{Kabupaten Tebo}

Jika terjadi perubahan belanja modal dan PMDN baik antar wilayah maupun antar waktu, maka Kabupaten Tebo akan mendapatkan pengaruh individual terhadap pertumbuhan ekonomi kabupaten/kota di Provinsi Jambi sebesar -5,022864 persen.

\section{Kabupaten Bungo}

Jika terjadi perubahan belanja modal dan PMDN baik antar wilayah maupun antar waktu, maka Kabupaten Bungo akan mendapatkan pengaruh individual terhadap pertumbuhan ekonomi kabupaten/kota di Provinsi Jambi sebesar 2,716660 persen.

\section{Kota Jambi}

Jika terjadi perubahan belanja modal dan PMDN baik antar wilayah maupun antar waktu, maka Kota Jambi akan mendapatkan pengaruh individual terhadap pertumbuhan ekonomi kabupaten/kota di Provinsi Jambi sebesar 1,039890 persen.

\section{KESIMPULAN DAN SARAN}

\section{Kesimpulan}

Realisasi belanja modal, PMDN dan pertumbuhan ekonomi di kabupaten/kota di Provinsi Jambi selama tahun 2011 sampai tahun 2017 mengalami perkembangan yang berfluktuasi. Ratarata perkembangan realisasi belanja modal terendah yaitu di Kabupaten Tanjung jabung Timur dan rata-rata perkembangan realisasi belanja modal tertinggi terjadi di Kabupaten Merangin. Rata-rata perkembangan PMDN terendah terjadi pada Kabupaten Merangin. Kemudian pertumbuhan ekonomi tertinggi tercatat pada Kabupaten Muaro Jambi, sedangkan pertumbuhan ekonomi terendah tercatat pada Kabupaten Tanjung Jabung Timur.

Berdasarkan hasil uji regresi data penel secara simultan menunjukkan belanja modal dan PMDN berpengaruh signifikan terhadap pertumbuhan ekonomi kabupaten/kota di Provinsi Jambi. Sedangkan secara parsial menunjukkan dari kedua variabel bebas hanya PMDN yang berpengaruh terhadap pertumbuhan ekonomi di kabupaten/kota Provinsi Jambi, sementara belanja modal tidak berpengaruh terhadap pertumbuhan ekonomi di kabupaten/kota Provinsi Jambi selama tahun 2011-2017.

\section{Saran}

Dampak belanja modal dan PMDN terhadap pertumbuhan ekonomi, menunjukkan hasil yang berbeda untuk berbagai penelitian. Untuk mendapatkan hasil yang lebih komprehensif, penelitian sebaiknya mencakup rentang waktu sekitar 10 tahun atau 15 tahun. Oleh karenanya, penulis menyarankan bagi yang tertarik dengan kajian ini, untuk menggunakan rentang waktu yang lebih panjang. Kemudian memasukkan variabel- 
variabel lain yang mempunyai teori keterkaitan terhadap variabel pertumbuhan ekonomi, sehingga cakupan penelitian lebih luas dan dalam melakukan uji asumsi hipotesis lebih signifikan.

PMDN di kabupaten/kota Provinsi Jambi berpengaruh positif dan signifikan terhadap pertumbuhan ekonomi. Oleh karena itu pemerintah kabupaten/kota hendaknya lebih meningkatkan investasi swasta terutama penanaman modal dalam negeri (PMDN) dalam bentuk mempermudah proses pengurusan izin-izin dan adanya keterpaduan koordinasi anatar departemen melalui jalur birokrasi. Perlu menciptakanstabilitas ekonomi makro yang mantap melalui program-program reformasi, deregulasi dan debirokratisasi di seluruh aspek pembangunan ekonomi. Dengan Upaya tersebut diharapkan dapat lebih menarik investor untuk menanamkan modalnya.

Upaya meningkatkan investasi PMDN dapat dilakukan pula peningkatan sumber pendanaan dan ketepatan alokasi investasi pembangunan melalui penciptaan iklim kondusif untuk pengembangan usaha dan penciptaan lapangan kerja, serta mengembangkan pemberdayaan masyarakat dan kemitraan dalam proses pembangunan dengan mengimplementasikan paradigma masyarakat membangun. Pembentukan perda yang demikian dapat mengembangkan "networking" atau jejaring kerja dan penciptaan iklim usaha yang kondusif, dengan memberi kemudahan pelayanan publik antara lain bernilaikan kesederhanaan, kejelasan, kepastian waktu, akurasi, keamanan, tanggung jawab, kelengkapan sarana prasarana, kemudahan akses, kedisiplinan, kesopanan, keramahan, dan kenyamanan.

\section{DAFTAR PUSTAKA}

Daniel, (2015). Analisis pengaruh pengeluaran pemerintah dan investasi terhadap kesempatan kerja, pertumbuhan ekonomi serta ketimpangan pendapatan Kabupaten/ Kota di Provinsi Bali periode tahun 2005-2013. Jurnal UNUD, 5 (7), 2123-2160

Gerardo P. Sicat., \& H.W. Arndt. (1991). Ilmu ekonomi untuk konteks Indonesia, penerjemah: Nirwono. LP3ES: Jakarta.

Gujarati, Damodar. (2011). Dasar-dasar ekonometrika. Erlangga: Jakarta.

Husnan., \& Pudjiastuti. (2012). Dasar-dasar manajemen keuangan (6th). UPP STIM YKPN: Yogyakarta.

Halim, A. Damayanti, (2004). Pengelolaan keuangan daerah. Seri Bunga Rampai Edisi Kedua: Jogyakarta.

Mardiasmo, (2002). Otonomi dan manajemen keuangan daerah, Andi: Yogyakarta.

Nasir. (2001). Metode penelitian. Jakarta: Ghalia Indonesia

Santoso, Irvan. (2016). Pengaruh belanja modal, penanaman modal dalam negeri, dan penanaman modal asing terhadap pertumbuhan ekonomi dan implikasinya pada pendapatan asli daerah: studi pada Kabupaten dan Kota di Provinsi Jawa Barat Tahun 2008-2013.S1 Thesis, Universitas Pendidikan Indonesia.

Sukirno. (2004). Ekonomi pembangunan. Borta Gorat: Medan

Todaro,Michael.P.(2006). Pembangunan ekonomi di dunia ketiga.alih bahasa: Amminudin dan Drs. Mursid. Ghalia Indonesia: Jakarta.

D Chandra, S Hidayat., \& R Rosmeli.(2017). Dampak dana perimbangan terhadap pertumbuhan ekonomi dan ketimpangan antar daerah di Provinsi Jambi, Jurnal Paradigma Ekonomika 12 (2), 67-76

M Latif., S Syaparuddin., \& E Achmad.(2017).Hubungan belanja daerah, PMDN, PMA, tenaga kerja dan pertumbuhan ekonomi Provinsi Jambi (Pendekatan Kausalitas Granger), e-Jurnal Perspektif Ekonomi dan Pembangunan Daerah 6 (2), 85-96 